\title{
Marija, Kristova majka, \\ u svjetlu jedinstva $i$ harmonije Svetoga pisma u misli \\ J. Ratzingera / Benedikta XVI.
}

\author{
BORIS VULIĆ* \\ • https://doi.org/10.31823/d.27.3.4 • \\ UDK: 27-312.47-05 Ratzinger, J. • Prethodno priopćenje \\ Primljeno: 12. rujna 2018. • Prihvaćeno: 9. rujna 2019. \\ >Da razumijevanje objave bude sve dublje, \\ isti Duh Sveti svojim darovima vjeru svudilj usavršuje « \\ (Dei Verbum, br. 5)
}

${ }^{*}$ Doc. dr. sc. Boris Vulić,

Katolički bogoslovni

fakultet u Đakovu

Sveučilišta J.J.

Strossmayera u Osijeku,

P. Preradovića 17,

p.p. 54, 31400 Đakovo,

Hrvatska, vulic@me.com

Sažetak: Cilj je članka upozoriti na temeljnu perspektivu čitanja Svetoga pisma, u kojoj se mogu ispravno razumjeti pojedini sveti tekstovi (prvi dio članka) i sveobuhvatnije tumačiti četiri marijanske dogme Crkve (drugi dio članka). U clanku se osobito slijedi nauk II. vatikanskoga koncila te misli Josepha Ratzingera / Benedikta XVI., koji je dao vrlo važan doprinos glede cilja ovoga rada. Tim se putem dolazi do temeljnih rezultata istraživanja: svete tekstove valja tumačiti u svjetlu jedinstva i harmonije Pisma te polazeći od njegova središta - Isusa Krista. Najprikladniji metodički postupak za takvo tumačenje jest tzv. kanonska egzegeza, koja pojedini biblijski tekst čita u svjetlu cjeline Staroga i Novoga zavjeta. Tu bitnu ulogu imaju sveta predaja, analogija vjere i tipološke interpretacije. Time je otvorena i perspektiva za razumijevanje suglasja marijanskih dogmi s Božjom objavom. Stoga se u Pismu uočavaju slojevi biblijske tradicije koji predstavljaju uporište za mariologiju $i$ marijanske dogme, a to su starozavjetna teologija žene i teologija Božjega naroda. Svi bitni elementi tih stvarnosti uosobljuju se u Mariji. Zato u Mariji Izrael, ali i Crkva postoje kao osoba, što je temeljna biblijsko-mariološka teza J. Ratzingera.

Ključne riječi: Sveto pismo, sveta predaja, egzegeza, marijanske dogme, Joseph Ratzinger / Benedikt XVI. 


\section{Uvod}

Naslov članka otkriva dva težišta ovoga rada. Prvo je težište vezano za Sveto pismo, a drugo za dogme, odnosno za svečano proglašene istine vjere o Blaženoj Djevici Mariji. Čini se da je današnji status tih dvaju težišta, sagledan u širem kontekstu crkvenoga života, obilježen nemalim problemima. Ti problemi donose paletu reperkusija ne samo za teološki svijet, svijet usko vezan za teologiju kao znanstveno polje, nego i u sasvim konkretni pastoralni život Crkve i duhovnost samih vjernika, sve do mjere u kojoj su Sveto pismo i otajstvo Isusove majke posve razvodnjeni i tako marginalizirani u raznim pastoralnim vizijama, kao i u mnogobrojnim oblicima biblijskoga pastorala.

Racionalizacija pristupa Svetome pismu, koja je posebno obilježila suvremenu teologiju, dovela je do općega uvjerenja kako je proučavanje Pisma radi dosezanja čiste objektivnosti njegova sadržaja zadaća posebne skupine eksperata. Tako je na primjer posve normalno da bibličar kritički oštro preispituje rezultate dogmatičara ili uvjerenja vjere Božjega naroda. Međutim obrnuti proces, u kojem bi dogmatičar ili obični vjernici vrjednovali uvide bibličara, kao da nije moguć. U takvom kolapsu na crkvene dogme počinje se gledati kao na otežavajuće stvarnosti na putu ispravnoga, objektivnoga razumijevanja onoga što nam Biblija doista govori. Između Biblije, dogmatike i osobne vjere uspostavljen je diskontinuitet koji uporno želi razlikovati objektivno od subjektivnoga te racionalno od iracionalnoga.

U takvom mentalitetu proučavanje osobe i otajstva Blažene Djevice Marije pripada sferi subjektivnoga (čije se mjesto tolerira u liturgijskim blagdanima i pučkim pobožnostima), ali i iracionalnoga, te se pokazuje kao nešto što nema važnih dodirnih točaka sa Svetim pismom. Tako bibličari koji to žele mogu danas mirno zastupati stav da je mariologija u svojoj biti puka katolička inačica raznih poganskih mitova.

Međutim ono što nam otvara obzorje nade jest činjenica da kroz cijelu povijest teologije, jednako kao i u naše dane, kod mnogih koje prepoznajemo kao velike teologe i učitelje vjere uočavamo to da Djevica Marija pripada samom srcu katoličke vjere, da ima središnje značenje za vjeru i to upravo zato što se takvo značenje utemeljuje u samom Svetom pismu i odatle je razvijano i produbljivano, slavljeno i ispovijedano. $U$ red takvih teologa zasigurno pripada i Joseph Ratzinger, danas papa emeritus Benedikt XVI. Kad bismo morali izdvojiti područja do kojih je Ratzingeru uvijek osobito stalo, onda bi u uži popis svakako trebao ući odnos između egzegeze i dogmatike. Toj temi, izravno ili neizravno, sustavno ili prigodno, posvetio je velik broj svojih promišljanja. Isto tako, ako bismo htjeli u njegovu opusu naći odgovor na pitanje što nikako ne smijemo zaboraviti u svojoj vjeri, onda bi u tom odgovoru važno mjesto zauzela Isusova majka. $U$ tom su nam se kontekstu njegova promišljanja učinila posebno prikladnima za cilj našega priloga, a to je da (ponovno) otkrijemo 
temeljnu perspektivu čitanja Svetoga pisma u kojoj možemo ispravno razumijeti pojedine svete tekstove (prvi dio članka) i u kojoj možemo sveobuhvatnije tumačiti i same marijanske dogme (drugi dio članka).

\section{Temeljna perspektiva čitanja Svetoga pisma}

\subsection{BIBLIJA KAO OTVORENA I ZATVORENA KNJIGA}

Sveto pismo u životu Crkve označeno je jednim velikim problemom koji se, u duhu Ratzingerovih promišljanja, može sažeti na sljedeći način: Sveto pismo danas se u Crkvi zapravo ne čita, a tamo gdje se čita ono se ne razumije u cjelini Božje objave. ${ }^{1}$ Povijesno-kritička egzegeza, koja posve legitimno istražuje što su biblijski pisci htjeli izreći u ono vrijeme i za ono vrijeme, težnjom za objektivnošću dovela je do nepregledna mnoštva hipoteza kojima se sve u Pismu željelo racionalno objasniti i često naturalizirati. Mnoštvo hipoteza i zahtjevi za objektivnošću zasigurno su dali svoj doprinos da se širem krugu vjernika zatvore vrata Svetomu pismu jer se proširio osjećaj neupućenosti u sve suptilne finese spomenutih hipoteza. Isto je, s druge strane, biblijske stručnjake odvelo do goleme usredotočenosti na pojedinačno, dijelom i sekundarno u Svetome pismu, pri čemu se iz vida izgubila ne samo cjelina Pisma nego i njegov živi odnos sa svetom predajom, a to znači i sa samom vjerom. Svi smo manje ili više svjedoci toga da tamo gdje povijesno-kritička metoda postaje dominantna metoda spram Svetoga pisma biblijska se teologija nužno pretvara u historicizam te na koncu u puku i nipošto izazovnu arheologiju, koja više ne zna ili ne želi znati za Crkvu kao živo i otajstveno tijelo Kristovo koje u svakoj svojoj epohi dublje ponire u svoju vjeru i iz nje rađa nove grane sigurnih istina. ${ }^{2} \mathrm{Zbog}$ svih tih pomaka možemo se složiti s Ratzingerom da je Sveto pismo danas istodobno otvorena i zatvorena knjiga:

»Primjenom povijesno-kritičkog tumačenja Pismo je postalo otvorena, ali i zatvorena knjiga. Otvorena knjiga: zahvaljujući radu egzegeze, riječ Biblije usvajamo na nov način, u njezinoj povijesnoj izvornosti, u raznolikosti jedne povijesti koja se događa i koja raste, a koja je bremenita onim napetostima koja su istodobno i njezino bogatstvo... ali, na ovaj način Pismo je postalo i zatvorena knjiga: postalo je objekt stručnjaka; laici, ali i teološki stručnjak

\footnotetext{
${ }^{1}$ Ovdje ćemo prikazati najvažnija Ratzingerova promišljanja o tumačenju Pisma, objavljena u knjizi J. RATZINGER, Riječ Božja. Pismo - tradicija - služba, Zagreb, 2012., osobito 41-128. O istom vrijedni su, među ostalim, i uvidi dani u: I. RAGUŽ, Joseph Ratzinger - Benedikt XVI. o egzegezi, 11-19. i M. VIDOVIĆ, Pristup i uvažavanje egzegetskih dostignuća u knjizi »Isus iz Nazareta « Josepha Ratzingera - Benedikta XVI., 37-74., u: I. RAGUŽ (ur.), Teološka promišljanja o knjizi »Isus iz Nazareta « Josepha Ratzingera / Benedikta XVI., Zagreb, 2009.

${ }^{2}$ Usp. J. RATZINGER, Maria Chiesa nascente, Cinisello Balsamo, 1998., 15.
} 
koji nije egzegeta, ne usuđuju se više o njoj govoriti. Čini se da je ono sad oduzeto vjernicima za čitanje i razmišljanje, pošto bi ono što iz toga proizađe bilo smatrano 'diletantskim'. Znanost stručnjaka podiže ogradu oko vrta Pisma koja je neprijelazna za nestručnjaka. $\ll^{3}$

Drugi vatikanski koncil u svojoj Dogmatskoj konstituciji o božanskoj objavi nedvojbeno naglašava važnost povijesno-kritičke egzegeze kada ističe važnost pozornoga istraživanja namjere biblijskih pisaca, odnosno onoga što su oni zaista kanili izreći, zatim istraživanja različitih književnih vrsti unutar svetih spisa, kao i uvažavanje onoga što se podrazumijeva pod sintagmom Sitz im Leben: konkretnoga povijesnog ambijenta u kojem nastaje pojedini biblijski spis, a koji se uvelike ocrtava $\mathrm{u}$ istom spisu. ${ }^{4}$ Međutim spomenuta konstitucija, zbog vjere da je Sveto pismo zapisano po nadahnuću Duha Svetoga, također traži da se pojedini biblijski tekstovi razumiju i tumače polazeći od cjeline jednoga Pisma:

$\gg$ No budući da Sveto pismo treba čitati i tumačiti $u$ istom Duhu u kojem je napisano, za ispravno pronicanje smisla svetih tekstova mora se s ne manjom brižljivošću gledati na sadržaj i jedinstvo cijeloga Pisma, uzimajući u obzir živu predaju Crkve i analogiju vjere. A stvar je egzegetâ da u skladu s tim pravilima rade na dubljem razumijevanju i izlaganju smisla Svetoga pisma kako bi takoreći iz prethodne poruke sazrio sud Crkve. Sve ono što se, naime, tiče načina tumačenja Pisma, u konačnici podliježe sudu Crkve, koja izvršuje božanski nalog i službu čuvanja i tumačenja Božje riječi. $\ll^{5}$

Prema tomu, kako primjećuje Ratzinger, polazna točka za razumijevanje Pisma jest njegovo jedinstvo. Put dubljega razumijevanja i izlaganja samoga Pisma jest analogija vjere, odnosno shvaćanje pojedinih tekstova u svjetlu njihove smještenosti u cjelinu Pisma. Takva polazna točka i put izviru iz dviju konstitutivnih istina o Svetome pismu: Bog je autor Svetoga pisma, a njegov stalni povijesni nositelj jest jedan Božji narod. U koncilskom nalogu da se svakako uzme u obzir živa predaja Crkve Ratzinger vidi naglašavanje načela po kojem sveta predaja zauzima važno mjesto, ako ne i najvažnije, u mjerilima izlaganja Svetoga pisma i točnosti njegova shvaćanja:

$\gg$ Pravilo vjere, danas kao i jučer, nije sastavljeno od otkrića (bilo pravih bilo hipotetskih) o biblijskim temeljima i slojevima, nego na Bibliji takvoj kakva jest, onoj koja je čitana u Crkvi od Otaca do danas. Vjernost ovakvu čitanju

\footnotetext{
${ }^{3}$ J. RATZINGER, V. MESSORI, Razgovor o vjeri. Jasni odgovori na suvremene dvojbe, Split, 2013., 67.

${ }^{4}$ Usp. DRUGI VATIKANSKI KONCIL, Dogmatska konstitucija o božanskoj objavi »Dei Verbum «, u: ISTI, Dokumenti, Zagreb, ${ }^{72}$ 2008. (= DV), br. 11-12.
}

${ }^{5}$ DV, br. 11 . 
Biblije dala nam je svece, često neuke, a često i nestručnjake u složenosti egzegeze. Ipak, oni su ti koji su je bolje shvatili. $\ll^{6}$

Drukčije rečeno, tradicionalno nipošto ne znači predznanstveno, iracionalno ili naivno. Stoga prethodno naznačeni suvremeni problemi kolapsa između egezegeze, dogamtike i vjere posve su neprirodni i neočekivani problemi jer:

>dogma kojoj je izmaknulo tlo Pisma više nije održiva. Biblija koja se odvojila od dogme postala je dokument prošloga i time sáma pripada prošlosti. (... ) Da bi se došlo do stvarnoga rješenja, mora se nadići spor oko detalja i doprijeti do korijena. Ono što nam je potrebno jest kritika kritike. $\ll^{7}$

\subsection{Relektura Svetoga Pisma}

Ta kritika kritike jest, zapravo, poziv na samokritiku pojedinih pristupa Svetomu pismu koji teže za apsolutnošću i objektivnošću, kojima je književna vrsta važnija od nutarnje povezanosti i harmonije Pisma. Dakako, spomenute devijacije unutar egzegeze svoje dramatične posljedice za vjeru posebno pokazuju na području kristologije. ${ }^{8} \mathrm{Iz}$ toga se onda događa urušavanje cjelokupnoga sadržaja vjere Crkve. Iako je teško nabrojiti sve dramatične posljedice za vjeru koje nastaju apsolutiziranjem povijesnokritičke metode i fokusiranjem samo na ljudsku stranu autorstva svetih spisa, ovdje ćemo, slijedeći Ratzingera, tek skicirati neke od tih poteškoća. Odmah valja istaknuti da se sve one u konačnici pokazuju kao zablude i to ne povijesne, nego filozofske naravi. Upravo kao takve utjecale su i na teološko i pastoralno udaljavanje od dogmatskih, a time i marioloških sadržaja, a sve uime objektivnoga pristupa Svetomu pismu.

Kao prvu poteškoću izdvajamo odnos starosti i istine. ${ }^{9} \mathrm{U}$ povijesno-kritičkom istraživanju lako se završi u aksiomu da je početno i izvorno ono što je jednostavnije, pa je prema tomu teološki složenija tvrdnja mlađa i ne može biti izvorna. Međutim to uopće ne može biti aksiom jer bi isto značilo da je, kako zamjećuje naš teolog, složena misao sv. Tome mlađa od jednostavnijih (kasnijih) misli njegovih učenika. Prema tomu starost ne može biti objektivno mjerilo istine.

Nadalje se u racionalizaciji pristupa Svetomu pismu drži da je moglo postojati samo ono što uvijek postoji, a tumačenje za sve što nadilazi taj aksiom valja pronaći u povijesnim procesima. ${ }^{10}$ Svi se dakle fenomeni u povijesti spasenja mogu i trebaju

\footnotetext{
${ }^{6}$ J. RATZINGER, V. MESSORI, Razgovor o vjeri, 68.

${ }^{7}$ J. RATZINGER, Riječ Božja, 106-107.

${ }^{8}$ Usp. B. VULIĆ, O jedinstvu i harmoniji Pisma, u: Communio, hrv. izdanje, 42(2016.)126, 2-4.

${ }^{9}$ Usp. J. RATZINGER, Riječ Božja, 113-116.

${ }^{10}$ Usp. isto, 121-123., 127-128.
} 
protumačiti prirodoznanstvenim metodama, vanjskim utjecajima ili, jednostavno, činjenicom da postoji Sitz im Leben ljudske riječi u Svetome pismu. Međutim $\gg$ nadahnitelj i začetnik « ${ }^{11}$ Pisma jest sam Bog i nipošto se ne može isključiti to da on sam može djelovati u povijesti na načine i kroz događaje koji nam se čine nevjerojatnima, koji nadilaze našu spoznaju i ono što razumijemo kao racionalno i prirodno. Prema tomu, budući da sam Bog djeluje u povijesti, moramo dopustiti - kako poziva Ratzinger - da nas svaki fenomen povijesti spasenja pouči, a ne samo da bude puki objekt koji valja racionalno protumačiti, odnosno naturalizirati.

To nas dovodi do trećega problema, koji vidimo u odnosu događaja i riječi unutar povijesno-spasenjskoga dinamizma Božje objave..$^{12}$ Racionalno razumjeti događaje značilo bi prihvatiti ih tek kao ilustraciju riječi, čime se sami događaji primiču sferi iracionalnoga ili kauzalnoga, po principu slučaja i nužnosti. Događaji zato ne mogu biti nositelji smisla, nego se oni trebaju pronaći u samoj riječi. Međutim teološki je besmisleno matricom racionalno - iracionalno međusobno odvajati riječ, smisao, događaj i povijest unutar Božje objave jer se

>raspored objave zbiva djelima i riječima iznutra međusobno povezanima tako da djela što ih je Bog izveo u povijesti spasenja očituju i potkrjepljuju nauk i riječima označene stvari, a riječi razglašuju djela i osvjetljuju u njima sadržano otajstvo $\ll^{13}$.

Dakako da je povijesno-kritička metoda nužna i važna za razumijevanje smisla Svetoga pisma. Svaki biblijski tekst ponajprije valja razumjeti u njegovu povijesnom kontekstu i tumačiti ga polazeći od namjere biblijskoga pisca jer su riječi Svetoga pisma najprije ljudske riječi. No to je uvijek i samo prvi korak, svojevrsna uvertira harmonije koju čini cjelina svetih spisa i jedan glas koji odjekuje u svim spisima, a to je glas same Božje objave. Spomenuta harmonija stoga zahtijeva tumačenje pojedinih spisa cjelokupnoga povijesnoga kretanja od Staroga do Novoga zavjeta s motrišta koje se smješta u samo središte cjeline, odnosno samo središte božanske objave koja nam je $\gg$ u punom svjetlu zasjala u Kristu, koji je ujedno i posrednik i punina sve objave $\ll^{14}$.

Pod vidom dosad rečenoga, najprije se trebamo kratko osvrnuti na odnos Pisma i svete predaje. ${ }^{15}$ Ako Pismo i predaja svoj izvor imaju u objavi, a to znači u Ri-

\footnotetext{
${ }^{11}$ DV, br. 16.

${ }^{12}$ Usp. J. RATZINGER, Riječ Božja, 129-131.

${ }^{13} \mathrm{DV}$, br. 2. Kurziv je naš.

${ }^{14}$ Isto.

${ }^{15}$ Usp. J. RATZINGER, Riječ Božja, 51-54.
} 
ječi Božjoj, Božjem govoru, kako naučava II. vatikanski koncil, ${ }^{16}$ onda stvarnost božanske objave prethodi Pismu i ne iscrpljuje se u svome zapisu, nego ostaje živa i djelotvorna kao predana Božja riječ u svetoj predaji. U skladu s tim objava postaje stvarnost jedino ondje gdje susreće vjeru. Objava je djelotvorna tamo gdje se, uz materijalni sadržaj ljudskim riječima zapisanoga Božjega govora, sama objava prihvaća na način vjere. Zato objavi bitno pripada i Božji narod, kao subjekt koji ju prima i bez kojega objava zapravo nije zamijećena, nije životvorna i djelotvorna i bez kojega sam narod ne bi bio uistinu Božji narod. Pismu dakle bitno pripada sama Crkva i to kao subjekt koji ga čita, produbljuje, razumije, razvija i tumači. ${ }^{17}$

Nadalje, budući da u ljudskim riječima govori sam Bog, tumačenje tih riječi nadilazi namjeru svetoga pisca i sam tekst, te zato izriče više od onoga što je pisac neposredno kanio izreći i čega je bio svjestan u ono vrijeme. Ratzinger se i kao rimski prvosvećenik vraćao na važnost ovoga više tvrdeći sljedeće:

»Ova nutarnja viša vrijednost riječi, koja nadilazi svoj trenutak, poglavito se odnosi na riječi koje su sazrele u procesu povijesti vjere. Tu autor ne govori jednostavno iz sama sebe i za sama sebe. On govori iz zajedničke povijesti koja ga nosi i u kojoj su istodobno već skriveno prisutne mogućnosti njezine budućnosti, njezina daljnjega puta. Proces daljnjega čitanja i razvoja riječi ne bi bio moguć da u samim riječima nije bila prisutna takva nutarnja otvorenost. $\ll{ }^{18}$

To više otkriva se kroz dinamizam koji Ratzinger naziva relektura (relectures). ${ }^{19}$ Riječ je o većoj značenjskoj povezanosti svetih spisa na temelju susreta Božjega naroda $s$ Božjom objavom, kroz čitanje i tumačenje pojedinoga biblijskoga teksta, u novom povijesnom kontekstu i u novom stupnju Božje objave. Taj se proces uočava već i u samoj Bibliji, gdje se iznova čitaju stari tekstovi, nanovo se shvaćaju i tumače. Tako se progresivno povezuju događaji i smisao, pri čemu riječi i događaji polako zadobivaju trajno mjerodavni puni smisao polazeći od Krista kao središta Pisma i kao onoga s kojim se i po kojem se zajedno čita Pismo i to od naprijed prema početku, od Novoga zavjeta prema Starom. ${ }^{20}$

\footnotetext{
${ }^{16}$ Usp. DV, br. 9.

${ }^{17}$ Usp. J. RATZINGER, Moj život. Autobiografija, Split, 2005., 80-81.

${ }^{18}$ J. RATZINGER / BENEDIKT XVI., Isus iz Nazareta, I., Split, 2007., 13.

${ }^{19}$ Usp. J. RATZINGER, Riječ Božja, 133-134.; J. RATZINGER / BENEDIKT XVI., Isus iz Nazareta, I., 12.

${ }^{20}$ Tako bi na primjer u teologiji stvaranja primat trebali imati novozavjetni tekstovi koji tematiziraju stvaranje (npr. Kol 1, 15-20; Iv 1, 1-5), odakle onda valja čitati, razumijevati i za vjeru cjelovito razvijati starozavjetne izvještaje o stvaranju (npr. Post 1-2).
} 
Dinamizam relekture možemo podijeliti u sljedeće četiri faze. ${ }^{21}$ (1) Postoji starozavjetna teologija Staroga zavjeta s dvama temeljnim procesima: povijesno istraživanje nutrine Staroga zavjeta te relektura, odnosno čitanje i tumačenje starih tekstova u svjetlu novih situacija. (2) Postoji novozavjetna teologija Staroga zavjeta koja nije istovjetna s prvom, ali je s njom iznutra povezana upravo po analogia fidei i to ponajprije kao novo tumačenje Staroga zavjeta polazeći od Krista. (3) Postoji novozavjetna teologija Novoga zavjeta sa sličnim procesima kao u prvoj teologiji: povijesno istraživanje nutrine Novoga zavjeta, ali i proces u kojem se novozavjetne predaje dublje shvaćaju i teološki promišljaju te se uobličuju u svete spise. I na koncu (4) postoji crkvena teologija Novoga zavjeta koju Ratzinger poistovjećuje s dogmatskom teologijom koja nastavlja već započete biblijske procese i relekture po kojima se sad u svjetlu cjeline jednoga Pisma izlaže predano i koja zato posjeduje jedno osobito više, koje je razlikuje od biblijske teologije i koje zapravo nazivamo svetom predajom. Ovdje bismo stoga nadopunili posljednju fazu relekture prema Ratzingeru i nazvali ju crkvenom teologijom Svetoga pisma.

Prema tomu tek u svjetlu Isusa Krista postaje razvidno što se uistinu htjelo reći starozavjetnom teologijom, a cjelina Svetoga pisma zadobiva puni smisao od Krista kao vrhunca i punine Božje objave, bez da se pojedinom spisu oduzima njegova povijesnost. Drugim riječima, mi ne čitamo Stari zavjet u njemu samome i radi njega samoga, nego ga čitamo u onome u kojem je taj Zavjet ispunjen i u kojem je zadobio stvarnu istinitost i mjerodavni puni smisao. Zato možemo govoriti o jednome pravcu Božje objave u Svetome pismu, čije je središte i ključ sam Krist, a zbog čega sve Pismo valjano produbljujemo ako ga čitamo s Kristom i po njemu. ${ }^{22}$

Ne čudi stoga što je kao metodički postupak Ratzingeru, i kao teologu i kao rimskom prvosvećeniku, posebno važan projekt tzv. kanonske egzegeze $\gg s$ nakanom čitanja pojedinačnih tekstova u cjelini jednoga Pisma, pri čemu se svaki od njih otkriva u novom svjetlu $\ll^{23}$. Zato se takvim pristupom može govoriti o istim i jedinstvenim povijesno-spasenjskim zakonima Božjega djelovanja, odnosno o istoj i jedinstvenoj božanskoj logici koja iznutra povezuje zapisani Božji govor u mnogostrukosti ljudskih izraza. U konačnoj pozadini kanonske egzegeze stoji uvjerenje da je kanon Svetoga pisma plod stupnjevite Božje objave čovjeku, da su ga napisali ljudi koje je nadahnuo Bog i da se sam kanon profilirao u vjeri i iz vjere Božjega naroda. Takav pristup Svetomu pismu utemeljen je na tradiciji, blizak je liturgijskom tumačenju svetih tekstova, uvažava analogiju i tipologiju te je nadasve znak vjere da su pojedini biblijski tekstovi dio jednoga biblijskoga kanona. Kanonska egzege-

\footnotetext{
${ }^{21}$ Usp. J. RATZINGER, Riječ Božja, 62-67.

${ }^{22}$ Usp. J. RATZINGER, U početku stvori Bog. Promišljanja o stvaranju i grijehu, Split, 2008., 21-30.

${ }^{23}$ J. RATZINGER / BENEDIKT XVI., Isus iz Nazareta, I., 11. Usp. ISTI, Maria Chiesa nascente, 30s.
} 
za stoga je konkretan metodički postupak koji provodi ključnu perspektivu za otkrivanje povezanosti svetih spisa međusobno, kao i njihovu povezanost sa svetom predajom. Time nam se ista perspektiva pokazuje i kao perspektiva za otkrivanje suglasja istina vjere, a to znači i marijanskih dogmi, sa Svetim pismom, te zato i s Božjom objavom, o čemu će sad biti više riječi.

\section{Božja objava, Sveto pismo i marijanske dogme}

\subsection{BIBLIJSKA UPORIŠTA MARIOLOGIJE}

Nutarnja povezanost cijele povijesti spasenja kao svoj najočitiji znak ima nutarnju povezanost Staroga i Novoga zavjeta. A ta se međusobna upućenost dvaju zavjeta za Ratzingera na poseban način izražava u osobi i otajstvu Blažene Djevice Marije. To je jedan od razloga zašto je mariologija bitna za ravnotežu same vjere, a to znači i za odnos Pisma i predaje, odnosno biblijske egzegeze i dogmatske teologije. Zato Ratzinger među svojih poznatih šest razloga zbog kojih ne smijemo zaboraviti Djevicu Mariju ${ }^{24}$ navodi i ove:

»Mariologija u Crkvi pretpostavlja ispravan odnos, potreban sklad između Biblije i Tradicije. Četiri marijanske dogme imaju neophodno potreban temelj u Pismu. Ali ovdje su to kao klice koje rastu i daju plod u toplom ozračju Tradicije onako kako se to izražava u liturgiji, $\mathrm{u}$ intuiciji vjerničkog naroda, $\mathrm{u}$ teološkom razmatranju vođenom od Učiteljstva. ( ... ) U osobi židovske djevojke, koja je postala Mesijinom majkom, Marija na živ i nerazdvojiv način povezuje stari i novi narod Božji, Izrael i kršćanstvo, Sinagogu i Crkvu. Ona je točka sveze bez koje vjera (kako se danas događa) riskira da se svede ili samo na Stari zavjet ili samo na Novi. U njoj pak možemo živjeti nutarnju povezanost cjelokupnog Pisma. $\ll^{25}$

To što se ovdje britko i sažeto formulira naš je teolog razvio u svojoj mariologiji koju je znakovito naslovio Kći sionska, ${ }^{26}$ a u kojoj je temeljno pitanje »postoji li uopće mjesto u Svetome pismu za nešto takvo kao što je mariologija $\ll^{27}$.

Jamačno da odgovor na to pitanje ne može doći ako se polazi od malobrojnih novozavjetnih mjesta koje izrijekom spominju Mariju (osobnim imenom samo 9 puta i to kod Mateja i Luke te pod pojmom Isusova majka i žena svega 10 puta u Novome zavjetu). Očito je dakle da se Marijina uloga ne može odrediti brojnošću izravnih

\footnotetext{
${ }^{24}$ Usp. J. RATZINGER, V. MESSORI, Razgovor o vjeri, 97-100.

${ }^{25}$ Isto, 98-99.

${ }^{26}$ J. RATZINGER, Kći sionska. Marijanska pobožnost u Crkvi, Split, 2008. U nastavku se rada oslanjamo na to djelo.

${ }^{27}$ Isto, 11.
} 
biblijskih citata. ${ }^{28}$ Stoga Ratzingerov put odgovora na postavljeno pitanje s pravom ide kroz istraživanje slojeva biblijske tradicije kako bi pokazao da je »slika Marije u Novomu zavjetu posve istkana od niti Staroga zavjeta $\ll{ }^{29} \mathrm{U}$ toj biblijskoj tradiciji dani su svi bitni elementi koji u sebi nose buduću, kasniju teologiju, odnosno mariologiju.

$\mathrm{Na}$ što se konkretno odnosi ta biblijska tradicija? Naš teolog upozorava na njezina tri sloja važna za našu temu. ${ }^{30} \mathrm{Na}$ prvoj razini stoji starozavjetna teologija žene, koja svoja konstitutivna mjesta crpi iz triju područja. Prvo se područje tiče same Eve koja je kao prva žena najdublje upućena na muškarca jer je stvorena od njega samoga, ali je istodobno i njegova nužna suprotnost. Eva i nakon prvoga grijeha ostaje majka živih, a to znači majka i čuvarica života spram smrti. Drugo područje odnosi se na parove starozavjetnih žena u kojima isprva jedna nasuprot drugoj stoje plodnost i neplodnost, ali se potom događa preokret kojim se začinje prava teologija djevičanstva - zemaljska neplodnost, odbačenost i nemoć postaju istinska plodnost (npr. Sara - Hagara, Rahela - Lea, Ana - Penina). Treće konstitutivno područje starozavjetne teologije žene jesu prave spasiteljice svoga naroda, poput Estere i Judite, koje tako uosobljuju nadu Božjega naroda te objavljuju Božju moć tako što sam Bog djeluje po njima za dobro svojega naroda.

Već taj kratki presjek otkriva starozavjetnu teologiju žene kao tipologiju u kojoj sam izabrani narod razumijeva i razvija svoju bit kao Božjega naroda, zbog čega se isti narod u svojoj samosvijesti doživljava kao žena, istodobno kao djevica i majka. Brak, odnosno zaručništvo, postaju znak i prijevod teologije saveza Boga i njegova naroda koja zato jest teologija ljubavi i žene. Međutim najbolje utjelovljenje, najrječitiji znak i najtočniji prijevod starozavjetne teologije žene, odnosno Božjega naroda, svoj konačni sadržaj zadobiva u Novom zavjetu, u Mariji, ženi koja je kao osoba istodobno majka i djevica. Starozavjetna teologija žene i Božjega naroda sada je postala osobom.

Jedinstvenost Marijine osobe Katolička Crkva ispovijeda u četirima marijanskim dogmama. To su sljedeće definirane istine vjere: Marija je Bogorodica, ${ }^{31}$ vazda

\footnotetext{
${ }^{28}$ Ako bismo se vodili time da važnost određuje brojnost spomena, onda bi Pilat ili Herod, koji se češće spominju od Marije, bili važniji od nje same, što je za vjeru posve neprihvatljivo. Usp. I. DUGANDŽIĆ, Marija, Isusova majka, u Novome zavjetu, Međugorje, 2008., 11-21.

${ }^{29}$ J. RATZINGER, Kći sionska, 11.

${ }^{30}$ Usp. isto, 14-25.

${ }^{31}$ Prva marijanska dogma proglašena je 431. godine na Efeškom saboru. Usp. H. DENZINGER, P. HÜNERMANN (ur.), Zbirka sažetaka vjerovanja, definicija i izjava o vjeri i ćudoređu, Đakovo, 2002. (=DH), br. 251-252.
} 
djevica, ${ }^{32}$ bezgrješno je začeta ${ }^{33}$ te je dušom i tijelom uznesena u nebesku slavu. ${ }^{34}$ Kako je poznato, za svaku dogmu vrijede dva bitna načela: da je njezin sadržaj istina sadržana u Božjoj objavi i da je taj sadržaj izričitom namjerom koncila ili pape proglašen kao siguran i obvezujući. ${ }^{35}$ Potonje načelo za svaku je marijansku dogmu moguće posve precizno povijesno odrediti. Stoga nam preostaje ispitati utemeljenje pojedine marijanske dogme u Božjoj objavi i to tako da čitamo zapisano svjedočanstvo te objave - Sveto pismo - te ga tumačimo polazeći od cjeline Svetoga pisma te od njegova središta koje je Krist, u kojem je sve Pismo ispunjeno i po kojem je sve Pismo iznutra povezano. ${ }^{36}$ Tako stupamo u svijet svete predaje.

\subsection{DJEVICA I MAJKA}

U svetoj predaji temeljna je marijanska istina da je Marija istodobno djevica i majka Boga i Gospodina Isusa Krista. ${ }^{37} \mathrm{U}$ tom kontekstu za našega teologa posebno je važna činjenica da evanđelist Luka Mariju prikazuje u posebnom i znakovitom odnosu s Božjim izabranim narodom, odnosno da se stari Izrael, točnije njegov sveti i vjerni ostatak, u punini vremena koncentrira u Isusovoj majci. ${ }^{38}$ To proizlazi iz očite paralele između Lukina izvještaja o anđelovu navještenju Isusova začeća (usp. Lk 1, 28-33), koji započinje riječima: »Zdravo [doslovno: Raduj se, nap. a.] milosti puna! Gospodin s tobom! « i riječi proroka Sefanije: »Kliči od radosti, Kćeri sionska, viči od veselja, Izraele! Veseli se i raduj se iz sveg srca, Kćeri jeruzalemska! Jahve te riješio tvoje osude, neprijatelje tvoje uklonio! Jahve, kralj Izraelov, u sredini je tvojoj! Ne boj se više zla!« $(3,14-17)$ Ovdje je očito da Luka radi tipološku identifikaciju, odnosno relekturu Marije i kćeri sionske.

${ }^{32}$ Druga marijanska dogma proglašena je vlašću pape Martina I. nakon Lateranske sinode održane 649. godine. Usp. DH, br. 503. Ta činjenica često se previđa te se navode neki crkveni sabori koji spominju Marijino trajno djevičanstvo, ali je ipak ne proglašavaju kao dogmu u današnjem smislu te riječi.

${ }^{33}$ Treću marijansku dogmu proglasio je 1854. godine papa Pio IX. Usp. DH, br. 2803.

${ }^{34}$ Četvrtu marijansku dogmu proglasio je 1950. godine papa Pio XII. Usp. DH, br. 3903.

${ }^{35}$ Te i druge bitne značajke dogmi u: W. KERN, F.-J. NIEMANN, Nauka o teološkoj spoznaji, Zagreb, 1994., 119-142.

${ }^{36} \mathrm{O}$ važnosti marijanskih dogmi za katoličku vjeru više u: I. RAGUŽ, Katolicizam, Đakovo, 2017., 37-53.

${ }^{37}$ Usp. J. RATZINGER, Kći sionska, 31-33.; 39-57.; ISTI, Maria Chiesa nascente, 53-59., 74-82.

${ }^{38}$ Takav pristup dijele i neki od suvremenih bibličara, uvjereni da povijesno-kritička metoda, uzeta sama za sebe, nije u stanju razumjeti Krista i njegovo otajstvo izraženo u starozavjetnim otajstvima. Vidi: A. VALENTINI, Maria secondo le Scritture. Figlia di Sion e Madre del Signore, Bologna, 2007., osobito 21-29., 403. 
Kći sionska zapravo je sinonim samoga Siona. Često u Pismu nailazimo na literarni fenomen po kojem jedan narod, kraj ili grad bivaju nazivani tako da se njihovu imenu doda riječ kći (kći babilonska, kći judina i sl.). U starozavjetnoj perspektivi Sion je mjesto posebne Jahvine nazočnosti, kao i mjesto nade u obećanja spasenja dana Davidovoj kući. Sion je zato imao poseban utjecaj na život i duhovnost Božjega naroda (usp. Ps $24 ; 26 ; 48 ; 76 ; 84 ; 87 ; 122 ; 137$ ). Tijekom vremena Sion će zapravo označavati sam Jeruzalem i cijeli Izrael, osobito pod vidom poziva da primi svoga obećanoga Spasitelja. ${ }^{39}$ Kći sionska tako izriče otajstvo saveza između Boga i njegova naroda, a u kontekstu starozavjetne teologije žene: Kći sionska kao zaručnica (usp. Hoš 1-3; Iz 62, 4-5), kao majka (usp. Ps 87; Iz 60, 1-7) i kao djevica (usp. Am 5, 1-6).

Marija je jedina osoba u povijesti spasenja koja je istodobno sve to - zaručnica, djevica i majka. ${ }^{40}$ Zato je ona Kći sionska u osobi i kao osoba. Marija je u svojoj osobi pravi Sion, ona je pravi Izrael u kojem se povezuju Stari i Novi zavjet te Izrael i Crkva. ${ }^{41}$ Marija je pravi starozavjetni Božji narod u osobi jer donosi plod po milosti - sam Gospodin sada je u sredini njezinoj. Biološku datost Marijina majčinstva valja tumačiti kao teološku stvarnost. Bog po Mariji djeluje na posve nov i jedinstven način u povijesti, ali se po njoj na nov i jedinstven način nastanjuje u svijetu. Tako se ispunjava najbitnije poslanje izabranoga naroda i označuje poslanje Crkve kao Božjega naroda koji je ušao u eshatološku fazu svojega postojanja. Zato Marija istodobno predstavlja, ali i nadilazi Izrael i to zato što je Marija Crkva u osobi i kao osoba. ${ }^{42}$

Nedvojbenu povezanost događaja navještenja Kristova rođenja sa starozavjetnom teologijom Ratzinger također vidi i u sljedećim riječima Evanđelja po Luki: »Duh Sveti sići će na te i sila će te Svevišnjega osjeniti.« $(1,35)$ Duh koji silazi upućuje nas na početke, na samo stvaranje te iz svjetla te cjeline sam nam se događaj navještenja otvara kao događaj novoga stvaranja koje započinje novim i jedinstvenim djelovanjem Duha u Kristovu dolasku. A slika sile Svevišnjega koja će osjeniti Mariju opet proizlazi iz starozavjetne teologije kulta te označuje oblak koji osjenjuje

\footnotetext{
${ }^{39}$ Usp. isto, 401-404.

${ }^{40}$ Usp. I. de la POTTERIE, Maria nel mistero del'alleanza, Genova, 1988., 23.

${ }^{41}$ Znakovit je naslov važne i opsežne studije: G. LOHFINK, L. WEIMER, Maria - nicht ohne Israel. Eine neue Sicht der Lehre von Unbefleckten Empfängnis, Freiburg im Breisgau, 2008. U njoj se na egzegetsko-dogmatski način pokazuje važnost shvaćanja Marije kao one u kojoj Stari i Novi zavjet, stari i novi Izrael postoje u osobi i kao osoba, što je osnovna Ratzingerova marijanska teza s kojom stoji u suglasju s mnogim suvremenim teolozima, od kojih ovdje izdvajamo tek dvojicu: $\mathrm{H}$. U. von BALTHASAR, Maria icona della Chiesa, Cinisello Balsamo, 1998.; H. de LUBAC, Meditazione sulla Chiesa, Milano, ${ }^{3} 1965 ., 397 \mathrm{~s}$.
}

${ }^{42}$ Usp. J. RATZINGER, Maria Chiesa nascente, 21. 
hram i tako jamči Božju nazočnost u njemu. Stoga se u Luke upravo »Marija pojavljuje kao sveti šator nad kojim postaje učinkovita skrivena Božja prisutnost $\ll^{43}$.

U tom kontekstu naš se teolog želi suočiti s jednim prigovorom, koji dolazi od gore opisanoga povijesno-kritičkoga pristupa Svetomu pismu, a to je pitanje podrijetla same predaje o Isusovu djetinjstvu koju u svojim zapisima prerađuju Luka i Matej. Rezultati novije egzegeze pokazuju da su evanđelisti, na temelju vlastitih teoloških naglasaka, učinili posljednje oblikovanje prethodnih predaja, koje su već formulirane u pojedinim crkvenim zajednicama. Takve rezultate Ratzinger vidi kao potvrdu činjenice da prethodna predaja, koja je postojala u užim krugovima ili manjim zajednicama, procesom preuzimanja i polaganjem u evanđelja tako ulazi u javni navještaj Crkve te postaje crkvena predaja u pravom smislu te riječi.

Nadalje primjećujemo da je najviše detalja o Isusovu rođenju donijelo Lukino evanđelje. To nipošto nije slučajno. Za našega teologa upravo taj podatak govori u prilog tezi da je jezgra Lukina izvještaja samo Marijino sjećanje, iz kojega je Luka crpio sadržaje za svoj zapis, koje je potom teološki promislio i razradio u svome evanđelju. ${ }^{44}$ Ovdje je važno uočiti sljedeće: za razliku od povijesno-kritičke egzegeze, koja u svom većem dijelu istinu mjeri starošću - pa izvorno zamjenjuje prastarim, Ratzinger nas upozorava da se razlika vezana uz jezgru ne odnosi na starost, nego na stupnjeviti razvoj značenja pojedinih predaja, u skladu sa stupnjevitim razvojem vjere prve Crkve o Kristu. Tako Pavlov postupak, koji Mariju spominje samo jednom - i to bez osobnoga imena (usp. Gal 4,4) - možemo nazvati preludijem onoga što je već postojalo kao predaja te je uzeto kao jezgra i teološki je obrađeno kod Luke te tako ušlo u javni navještaj Crkve.

Naravno, time nismo posve odgovorili na pitanje zašto su prethodne privatne objave o Isusovu začeću i rođenju iz uskoga kruga postale javni navještaj Crkve. Prema našem teologu, za to su postojala dva temeljna razloga. Isusovo začeće i rođenje događaji su u kojima sam Bog djeluje tako da počinje iznova, na radikalno nov i drukčiji način. Iz toga slijedi da se događaj Kristova rođenja može dogoditi samo onoj za koju na radikalan način vrijede riječi proroka Izaije: »Kliči, nerotkinjo, koja nisi rađala; podvikuj od radosti, ti što ne znaš za trudove! « $(54,1)$ Ovdje smo opet u samoj srži teologije Božjega naroda, koja je, kako smo vidjeli, bitno označena teologijom žene - slabi i neplodni Izrael sada donosi jedinstveni plod Božjega djelovanja. Obećanje proroka Izaije zato postaje konkretna stvarnost u Mariji:

\footnotetext{
${ }^{43} \mathrm{~J}$. RATZINGER, Kći sionska, 41.

${ }^{44} \gg$ Tvrdnjom koja se u pripovijesti o djetinjstvu [Isusovu] ponavlja dvaput, da je Marija čuvala riječi u svojemu srcu (usp. Lk 2, 19.51), Luka ukazuje, kako je rečeno, na izvor iz kojega crpi za svoje propovijedanje.« J. RATZINGER / BENEDIKT XVI., Djetinjstvo Isusovo, Split, 2012., 142. Usp. isto, 135 .
} 
$\gg$ U Isusu je Bog usred neplodna i beznadna čovječanstva postavio novi početak koji nije rezultat njegove vlastite povijesti nego dar odozgo. S njim započinje novo utjelovljenje. Za razliku od svih izabranih prije njega, on ne prima samo Duha, nego je u svojoj zemaljskoj egzistenciji samo po Duhu i zbog toga je ispunjenje svih proroka: istinski prorok. Tako i Marija, neplodna-blagoslovljena, postaje znak milosti - znak onoga što je istinska plodnost i spašenost: široka otvorenosti, koja se prepušta Božjoj volji. ${ }^{45}$

Kako je poznato, Isusovo rodoslovlje donose i Luka i Matej. U njemu Josipova linija upućuje na Davida, kako bi se upozorilo na Isusovo mesijanstvo. Međutim, što je još važnije, $u$ istim rodoslovljima rođenje od Marije Djevice upućuje na Isusovu bit, a to je sinovstvo koje je plod njegove relacije s Ocem nebeskim. Upravo se iz toga sinovstva treba pročistiti krivo razumijevanje starozavjetnih obećanja o Mesiji (relektura!). K tomu roditi Očeva Sina

>uključuje napuštanje same sebe i ulaženje u neplodnost; sada postaje jasno zašto je neplodnost uvjet plodnosti - tajna starozavjetnih majki postaje razvidna u Mariji. Ona zadobiva smisao u kršćanskome djevičanstvu koje započinje u Mariji $\ll^{46}$.

Marijino trajno djevičanstvo, posebno od vremena prosvjetiteljstva pa sve do danas, najosporavanija je marijanska dogma. To je osporavanje kanilo Marijino trajno djevičanstvo, zasvjedočeno u predaji, tumačiti duhovno i simbolički, a nikako kao stvarnu činjenicu povijesti. Tako se opet grubo odvaja biološko i teološko, pri čemu biološko nema više nikakvu ulogu za teološko, ali i obratno. Povijesno-kritičko mišljenje tomu je dalo znatan doprinos. Ratzinger ga vidi u hipotezama kako je kod Marijina trajnoga djevičanstva riječ o kasnim tradicijama koje su naknadno dodane. Međutim, kako je već istaknuto, starost nije mjerilo istine. Prema tomu nijedno povijesno-kritičko mišljenje ne može pobiti to da sama jezgra pojedinih biblijskih tradicija može biti starija od konačne, stupnjevito i u skladu s pojedinim teološkim naglascima razvijane i formulirane biblijske tradicije. Mnogo je važnije mjerilo to da se dvije tradicije, koje su neovisne jedna o drugoj i koje su oblikovane prema različitim naglascima, kao što je slučaj u Mateja i Luke po pitanju Marijina djevičanstva, podudaraju upravo pod vidom iste jezgre.

Sljedeći argument kojim se nastoji dovesti u pitanje Marijino trajno djevičanstvo, odnosno Isusovo rođenje od Djevice, polazi od prirodoznanstvenoga tumačenja svijeta, koje svoje reperkusije unosi i u samu sliku Boga i njegova djelovanja. Naime, kako smo ranije i spomenuli, u prirodoznanstvenom mentalitetu ono što je

\footnotetext{
${ }^{45} \mathrm{~J}$. RATZINGER, Kći sionska, 45.

${ }^{46}$ Isto, 48.
} 
posve nevjerojatno u svijetu postaje posve nevjerojatno i za samoga Boga. Iza toga se krije uvjerenje da Bog ne može djelovati u biološkome i u samoj materiji, već se njegovo djelovanje - dualistički - ograničava na prostor duhovnoga. Sada vidimo koliko je uistinu teološki važna istina Isusova rođenja od Djevice jer time stoji ili pada temeljna istina povijesti spasenja o Bogu koji djeluje u povijesti i koji može djelovati na radikalno novi način - u duhovnome, ali i u biosu, u materiji, u tjelesnom, posebno onda kad je po ljudskim mjerilima riječ o neplodnome, neznatnome i odbačenome.

Zaključimo pogled na te dvije marijanske dogme posebno jasnim primjerom Ratzingerova kanonskoga čitanja Svetoga pisma:

$\gg$ Kod Ezekiela, u 40. poglavlju, dana je vizija novoga hrama u kojoj se govori o 'istočnim vratima', kroz koja smije ući samo kralj. Oci su u tome vidjeli sliku. Oni polaze od toga da je novi hram živi hram: živa Crkva. Vrata kroz koja je ušao on i kroz koja ne smije ući nitko drugi - tko je ili što je to ako ne Majka Marija? Ona koja je rodila Boga ne smije se više spustiti među obične ljude. Ona ostaje u ulozi vrata koja pripadaju samo kralju. I ona je upravo time postala istinskim vratima koja vode u povijest, kroz koja ulazi onaj koga svi čekaju. ${ }^{47}$

\subsection{BEZGRJEŠNO ZAČEĆE}

Dogma o Marijinu bezgrješnom začeću, odnosno jedinstvenu začeću koje je Božja milost unaprijed očuvala od istočnoga grijeha, prema Ratzingeru, danas se posebno susreće s dvama prigovorima. Prvi kaže da cijelo tisućljeće Crkva o tome ne zna ništa, pa je ta dogma na neki način spekulativno prekoračivanje granica. Drugi pak u toj dogmi vide osporavanje sveopćega spasenja u Kristu, jer kako je Marija otkupljena i spašena, ako nije imala (barem) iskonski grijeh. Ti prigovori pokazuju da se i u slučaju te marijanske dogme Božjoj objavi pristupa bez odlučujuće svijesti o jedinstvu Staroga i Novoga zavjeta, u kojem se tipološki otkriva njihova podudarnost i povezanost, analogija, kao i sličnost u nesličnosti te jedinstvo u različitosti.

Oslanjajući se na uvide franjevačkoga teologa B. Langemeyera, naš teolog upozorava na starozavjetni sveti ostatak Božjega naroda Izraela, koji je vrlo važna datost starozavjetne teologije, ako trajno čuva i živi svoju vjernost Bogu, te će ga zato Bog spasiti. Naime, koliko god se Izrael otuđio od Boga i koliko god ih je Bog kaznio povlačenjem svoje slave, povijest spasenja uvijek pamti jedan mali dio izabranoga naroda koji Bogu ostaje vjeran, a to na neki način znači i bezgrješan, odnosno onakav kakvim ga Bog hoće, kako bi mogao primiti Božje spasenje i biti znakom Božje-

${ }^{47}$ J. RATZINGER, P. SEEWALD, Bog i svijet. Vjera i život u našem vremenu, Zagreb, 2003., 253-254. 
ga djelovanja u svijetu. Sveti ostatak, po Božjoj volji, čuva kontinuitet saveza Boga i njegova naroda, koji je prvim grijehom i grijehom cijeloga naroda narušen, ali ne i dokinut. Ideju takvoga svetoga ostatka, koji predstavlja kontrapovijest grijehu, apostol Pavao vidi ostvarenom upravo u Kristovoj Crkvi: $\gg I$ u sadašnje vrijeme postoji Ostatak po milosnom izboru.« (Rim 11,6) Crkva je dakle novi sveti ostatak koji i dalje čuva kontinuitet saveza Boga i čovječanstva te ostaje biti znakom da Božja riječ sigurno donosi plod tako što će sigurno naići na slobodno i potpuno predanje kroz ljudski odgovor na božanski poziv. Točka u kojoj taj odgovor postaje konkretnom ljudskom osobom jest Marijin odgovor milosti - ona je sva taj odgovor:

$\gg$ Ona je posve Židovka, posve je dijete Izraela, Staroga zavjeta, a upravo time i dijete Saveza općenito, posve je kršćanka: Majka Riječi. Zbog toga budući da je ona Novi zavjet u Starome, odnosno kao Stari zavjet, kao Izreal - nema shvaćanja njezina poslanja, njezine osobe, ondje gdje se razdvajaju Stari i Novi zavjet. ${ }^{48}$

U svjetlu svetoga Ostatka koji čuva kontinuitet saveza Boga i čovjeka spoznajemo da je odnos Boga i čovjeka narušen, odnosno da je istočnim grijehom ranjeno ono što je čovjek u svome odnosu s Bogom. Marija koja je po Božjoj milosti, Kristovim, a ne svojim zaslugama, unaprijed očuvana od istočnoga grijeha pokazuje da čuvanje kontinuiteta saveza Boga i čovjeka, što je uvijek i čuvanje izvorne čovjekove biti promatrane kroz njegov odnos s Bogom, ne postoji samo apstraktno ili kao ideal, nego je ostvaren i živi u osobi i kao osoba te je tako milost očuvala ljudsku stranu Staroga zavjeta i dala mladicu iz koje se rađa Novi zavjet.

Sada se još jednom trebamo prisjetiti temeljnoga određenja Eve kao prve žene i prve lekcije starozavjetne teologije žene. Ona je stvorena od Adama, posve je od drugoga, ali ujedno i jest njegova suprotnost. Tu bit žene na jedinstveni način otkriva i objavljuje Marija, ako je ona stvorenje posve od Boga, najdivniji plod njegove milosti, koja pred samim Bogom postoji kao njegova nasuprotnost, ali kao čisto stvorenje koje može slobodno izreći svoj potpuno vjerni, a to znači bezgrješni odgovor spram njegova poziva. ${ }^{49}$ Marija je dakle sveti ostatak u osobi i kao osoba.

Dakako da se nameće pitanje odakle nam pravo da Mariju tako izjednačimo sa svetim Ostatkom Izraela. Ratzinger nas vodi u Poslanicu Efežanima $(5,27)$, gdje se o Crkvi, tom novom Izraelu, govori u terminima slavna, bez ljage, bez nabora, sveta i bez mane. Crkvena tradicija, sve od otačke teologije, upravo je, polazeći od toga

\footnotetext{
${ }^{48}$ J. RATZINGER, Kći sionska, 61.

${ }^{49}$ Znakovito je da se čisto stvorenje, čovjek po Božjem naumu, u punini vremena pojavljuje upravo u ženi - Mariji. Time je dana posebna vrijednost i starozavjetnoj teologiji žene. Usp. J. RATZINGER, Maria Chiesa nascente, 24-25., bilj. 17.
} 
novozavjetnoga mjesta, isprva razvijala nauk o Ecclesia immaculata. Kasnije, produbljujući ekleziologiju koja se shvaćala i kao mariologija, isti su pojmovi preneseni na Mariju, čime je potvrđeno da je Marija početak i uosobljenje Crkve, odnosno Crkva u osobi. Model i tip Gospodinove Crkve, i to onakve kakvu ju on želi, u Mariji je dan kao osoba. $\mathrm{Na}$ temelju toga dodatno je potvrđeno da novi Izrael, koji zapravo jest vjerni i bezgrješni sveti ostatak staroga Izraela, postoji i kao osoba. Da je takav put tumačenja ispravan, pokazuje i već spomenuto Lukino tipološko predstavljanje Marije kao Kćeri sionske koja u svome djevičanskom majčinstvu, a to znači u samoj svojoj osobi, postaje ispunjenje biti stare Kćeri sionske te istodobno nova Kći sionska. Dakle bit Izraela i Crkve tu se susreću u istoj osobi.

\subsection{UZNESENA DUŠOM I TIJELOM U SLAVU NEBA}

Prema dostupnim istraživanjima, svjedočanstva u tradiciji Crkve, koja bi se mogla uzeti kao izvori o Marijinu uznesenju, ne počinju prije 6. stoljeća. Već upoznatom logikom racionaliziranja i naturalizacije unutar povijesno-kritičkoga mišljenja, lako se dolazi od prigovora da i četvrtu marijansku dogmu valja shvaćati samo duhovno, bez njezine povijesne i biološke dimenzije kao sastavne činjenice teološke istine.

Kako nam je poznato, četvrta marijanska dogma nije proglašena zbog nekoga prijetećega krivovjerja po tom pitanju. Taj podatak još više upozorava na to da je pogonska snaga, kako se izražava Ratzinger, za tu istinu vjere bilo (liturgijsko) štovanje Marije u Crkvi. Tako dolazimo do onoga što marijanske dogme općenito i trebaju biti - čin štovanja, vrst pohvale, svojevrsni marijanski himan. Prema tomu, općenito gledano, dogme nemaju samo svoju povijesnu ulogu u pobijanju hereza, nego one sadrže i doksologiju te, u ovom konkretnom slučaju, žele biti najviše štovanje Djevice Marije kroz sigurnost vjere združenu s liturgijom vjere. ${ }^{50}$

Osim doksološkoga elementa Ratzinger primjećuje suglasje četvrte marijanske dogme s drugim trima marijanskim dogmama. Tako Marija, uznesena na nebo, povratno upozorava na njezino bogomajčinstvo, odnosno na novost rađanja usred onoga staroga rađanja gdje je, počevši od Eve, rođenje istodobno značilo i otvaranje umiranju. Novo rođenje po Mariji donosi smrt same smrti, ono je vječno postojanje, ako je Marijin sin uskrsnuli i proslavljeni Krist. Život koji se začinje u Mariji nov je i čist početak iza kojega ne dolazi smrt te kao takav unaprijed upućuje na Marijino uznesenje, ali i na Marijino djevičanstvo. Dogma o Marijinu uznesenju povezana je i s njezinim bezgrješnim začećem jer milost u njoj ne postoji na način na koji postoji u svakom drugom čovjeku koji je istodobno svet i grješan. Marija je milosti puna, te je zato punina spasenja Mariju zahvatila od časa samoga njezina

${ }^{50}$ Dok se na kršćanskom Istoku čin štovanja ponajviše događao kroz liturgiju, himan i obred, na Zapadu se događalo da se za primarno izabirao put dogme. Usp. J. RATZINGER, Kći sionska, 69. 
začeća. Zato je ona sva sveta i sva bezgrješna. U njoj dakle nema prostora za grijeh, pa ni za užas smrti koji ga prati. Punina milosti jest punina spasenja zbog koje je Marija kao čitav čovjek, i dušom i tijelom, Božjom snagom uznesena u slavu neba.

Smisao je dakle dogme o uznesenju da je Djevica Marija potpuno i cjelovito u eshatološkom zajedništvu s Bogom. Tako je na razinu sigurnosti vjere podignuto ono što je bitna pretpostavka štovanja svetih, pa je ovdje riječ o, kako piše naš teolog, najvišem stupnju kanonizacije, pri čemu se pojmom svet koristimo u najradikalnijem smislu: štovanje Djevice Marije ima smisla samo ako je Marija, dušom i tijelom, u Bogu. Konačna spašenost Djevice Marije, koja je Crkva u osobi i u kojoj Crkva postoji kao osoba, zapravo je i znak eshatološkoga smisla čovjekove besmrtnosti te znak konačne spašenosti same Crkve jer u Uznesenoj ta spašenost ne postoji na način obećanja, nego kao ostvarena činjenica.

Svjetlo za tu istinu valja primiti iz Pavlove teologije krštenja: »Ali Bog, bogat milosrđem, zbog velike ljubavi kojom nas uzljubi, nas koji bijasmo mrtvi zbog prijestupâ, oživi zajedno $s$ Kristom - milošću ste spašeni! - te nas zajedno s njim uskrisi i posadi na nebesima u Kristu Isusu.« (Ef 2, 4-6) Ovdje je za našega teologa riječ o svojevrsnom uzašašću samoga krštenika, što jest potpuno ostvarenje krštenja. Krštenjem čovjek postaje združen s Kristovim uskrsnućem, a to znači i s njegovim uzašašćem. Ako tu istinu stavimo uz Lukino svjedočanstvo o Marijinoj bezgraničnoj vjeri (usp. Lk 1, 45), što predstavlja pravi sadržaj i bit samoga krštenja, tada postaje razvidno da

>dogma, dakle, govori samo to da se u Mariji potpuno ispunilo ono što dobivamo krstom, naime stanovanje ('imati mjesto') s Bogom 'na nebesima' (Bog je nebo!). Krst (jedinstvo s Kristom) ostvario je svoje puno djelovanje. Kod nas je zajedništvo $s$ Kristom još lomljivo, nesigurno. Kod nje nije. Kod nje više ništa ne nedostaje. Ona je ostvarila potpuno zajedništvo s Kristom. A uz to zajedništvo ide i nova tjelesnost, koju mi ne možemo zamisliti. Ukratko rečeno: Bit te dogme sastoji se u tome što je Marija cijelim svojim bićem kod Boga, kod Krista, cijelim svojim bićem 'kršćanka' ${ }^{51}$.

\footnotetext{
${ }^{51}$ J. RATZINGER, P. SEEWALD, Bog i svijet, 255. Prava je šteta što Ratzinger nije ovdje razvio Marijino uznesenje u svjetlu povijesno-spasenjskoga događanja poniženja i uzvišenja, što bi dodatno potvrdilo i pojasnilo važnost kanonske egzegeze i tipološkoga tumačenja Svetoga pisma, ako se u Božjoj objavi posve jasno može uočiti povijesno-spasenjski zakon poniženja $i$ uzvišenja koji se jedinstveno ocrtava u hvalospjevu Veliča, odnosno u Mariji, neznatnoj Božjoj sluškinji, koja je na nebo uznesena. Vrijedne sadržaje o tome nalazimo kod: S. DE FIORES, Maria Madre di Gesù. Sintesi storico-salvifica, Bologna, ${ }^{4} 2002 ., 212$ s. Usp. također: B. VULIĆ, Uznesenje Djevice Marije na nebo i Božje djelovanje po poniženju i uzvišenju. Promišljanja na tragu Carla Gustava Junga i Stefana De Fioresa, u: D. DAMJANOVIĆ-BARIŠIĆ, I. RAGUŽ, B. VULIĆ (ur.), Gospi Tekijskoj. Zbornik radova, Đakovo, 2017., 99s.
} 
Tako smo se još jednom vratili temeljnoj Ratzingerovoj tezi da u Mariji Božji narod - Crkva postoji u osobi i kao osoba te smo došli do naših zaključnih promišljanja, u kojima ćemo izdvojiti tek perspektive za koje nam se čini da su važne za relekturu i Svetoga pisma i otajstva Isusove majke u teologiji i pastoralu Crkve.

\section{Zaključak}

1. Načelo sola Scriptura nije moguće shvatiti na apsolutni način jer samom Pismu, kao zapisanom svjedočanstvu Božje objave, bitno pripada i Božji narod, odnosno Crkva koja ga kao subjekt prima i prihvaća te ga cita, razumijeva, produbljuje i razvija. U tom smislu čitanje Pisma podrazumijeva i slavljenje liturgije Crkve, koja je jedinstveno mjesto navještaja i tumačenja Pisma, zatim slušanje učiteljstva Crkve, koje mjerodavno čuva ono božansko izraženo u ljudskome, kao i osluškivanje teologije, koja istražuje suodnos božanskoga i ljudskoga u jedinstvu samoga Pisma.

2. Sveto pismo čine 73 knjige iznutra povezane jedinstvenim glasom Božje objave, koji se može čuti u svim pojedinim svetim tekstovima. Povijest Božje objave, povijest njegova djelovanja, kao i povijest Božjega naroda iznutra su povezani istom milošću. Stoga pojedini tekstovi Svetoga pisma nisu tek tekstovi koji su sabrani pod jedan naslov, nego su dijelovi zapisanoga svjedočanstva jedne Božje objave, te se zato u punom smislu razumiju samo ako se čitaju u svjetlu cjeline, odnosno u samoj cjelini Pisma te polazeći od njegova središta koje je Krist, kao vrhunac i punina Božje objave. Ili, kako je to sažeo II. vatikanski koncil: »Bog, nadahnitelj i začetnik knjiga obaju zavjeta, tako je mudro rasporedio da je Novi zavjet u Starom skriven, a u Novom Stari otkriven. $\ll{ }^{52}$ Pismo dakle valja tumačiti samim Pismom. To nije samo metodički postupak niti jedan od mogućih pristupa koji stoji uz bok drugim pristupima, nego glavni cilj svakoga drugoga pristupa te mjerodavni kriteriji za uočavanje granica povijesno-kritičkoga mišljenja.

3. Povijesno-kritičko istraživanje Svetoga pisma koje bi težilo posvemašnjoj racionalizaciji i naturalizaciji biblijskih tekstova bilo bi izraz ropstva povijesnosti i neozbiljan stav spram vjere u božansko nadahnuće Pisma. Tzv. kanonska egzegeza, tipološko, odnosno analoško razumijevanje nutarnje povezanosti Staroga i Novoga zavjeta, duhovni smisao svetih tekstova i sl. posebni su metodički postupci koji uvažavaju dinamiku i dubinu Božje objave te dinamiku i dubinu vjere koja susreće tu objavu. U takvim pristupima, za razliku od povijesno-kritičke egzegeze uzete same za sebe, sigurnije dolazi do izražaja jedinstvo i harmonija Pisma, što je conditio sine qua non da ono bude u Crkvi zaista čitano kao otvo-

${ }^{52}$ DV, br. 16. 
rena knjiga za svakoga pojedinoga vjernika. Isto dolazi kao preduvjet jasnijega shvaćanja liturgijskoga rasporeda navještaja Božje riječi, kao i njezina važnost za život Crkve uopće. Zato treba postati osjetljiviji spram svih konkretnih koraka koji omogućuju bolje razumijevanje Pisma na temelju načela da se Pismo treba tumačiti samim Pismom u duhu svete predaje. Ovdje ponajprije mislimo na stupnjevito uređene i za sve uzraste prilagođene župne biblijske skupine, forume, tribine, župno, ali i osobno čitanje cijeloga Pisma, biblijska bdijenja i sl., što će poticati i konkretno provoditi načela jedinstva i harmonije Pisma. To također uključuje napuštanje prakse tiskanja nepraktičnih, luksuznih i skupih izdanja Svetoga pisma, zatim odvojeno tiskanje Staroga i Novoga zavjeta, kao i tiskanje džepnih izdanja koja to, zapravo, uopće nisu itd..$^{53}$

4. Osoba i otajstvo Isusove majke Marije jedinstveno upućuje na unutarnju povezanost Staroga i Novoga zavjeta, Izraela i Crkve te na neki način postaje jamstvo duhovnoga, odnosno teološkoga razumijevanja Pisma koje ujedno i jest razumijevanje Božje objave. Vidjeli smo da je Marijin novozavjetni prikaz izrađen i od prethodne (usmene) predaje, koju su onda evanđelisti teološki promislili i protumačili na putu dubljega shvaćanja Isusa Krista, i od starozavjetne teologije. Sve bitne oznake starozavjetne teologije Božjega naroda, teologije žene te proročkoga navještaja o Kćeri sionskoj utkane su u Mariji, Isusovoj majci, i to na takav način da se može govoriti o uosobljenju svih bitnih oznaka navedenih stvarnosti u Mariji, ali i o njihovu nadilaženju, ako se u Marijinoj osobi, kao u ikoni, otkriva model i tip same Kristove Crkve, onoga što ona jest i onoga što će ona biti. Kanonska egzegeza omogućuje da Mariju otkrijemo u svjetlu jedinstvenoga Božjega nauma spasenja čovječanstva. U Mariji se sažima čitava povijest Izraela, sa svom milošću koja je u njemu djelovala. U njoj se otkriva i Crkva kao zajednica koja sluša, vjeruje, prima i čuva Božju riječ. Štoviše, »Marija je najdublje ušla u povijest spasenja te na neki način u sebi ujedinjuje i odražava najveća načela vjere $\ll^{54}$.

5. Sva kasnija mariologija, kao i marijanske dogme Crkve proizlaze upravo iz te dinamike uosobljenja Božjega naroda, a to znači Izraela i Crkve, u Mariji, koja tako čuva kontinuitet Božjega naroda koji poslušno i predano prima Božju objavu, čiji kontinuitet čuva Krist kao vrhunac i punina objave. Ovdje još jednom uviđamo važnost tipološke, odnosno kanonske egzegeze koja osvjetljava i samu sigurnost dogmi, ako pokazuje da se izvorno svetopisamsko razvija već u samom

${ }^{53} \mathrm{O}$ takvim problemima kratko je upozoreno u: B. VULIĆ, Živo jedinstvo Pisma, u: Vjesnik Đakovačko-osječke nadbiskupije i Srijemske biskupije 146(2018.)1, 1.

${ }^{54}$ DRUGI VATIKANSKI KONCIL, Dogmatska konstitucija o Crkvi »Lumen gentium «, u: ISTI, Dokumenti, Zagreb, ${ }^{7} 2008$., br. 65. 
Pismu, što omogućuje i nastavak te izgradnje (relekture) u svetoj predaji Crkve. Isto tako posve je razvidno da gubitak osjećaja za jedinstvo Pisma sigurno dovodi do gubitka pozornosti za mariologiju. Tako se i ovdje, kao i u mnogim drugim pitanjima vjere, mariologija otkriva kao pokazatelj je li pristup Svetomu pismu ispravno postavljen ili nije. Stoga, ako nam je stalo do Svetoga pisma, treba nam biti stalo i do toga da Isusova majka bude češća tema biblijsko-teoloških studija, kao i do toga da bude draga tema biblijskih skupina i seminara te svih oblika biblijskoga pastorala koji će tako postati ono što uistinu treba biti - proces (ponovnoga) zajedničkoga otkrivanja sensus plenior Svetoga pisma. 


\section{MARY, MOTHER OF CHRIST, IN THE LIGHT OF THE UNITY AND HARMONY OF SACRED SCRIPTURE IN THE THOUGHT OF J. RATZINGER / BENEDICT XVI}

\section{Boris VULIĆ*}

Summary: The aim of the article is to point out the basic perspective of reading the Sacred Scripture, where individual sacred texts (the first part of the article) can be correctly understood and the four Marian Church dogmas (the second part of the article) can be interpreted more comprehensively. The article specifically follows the teachings of the Second Vatican Council and the thoughts of Joseph Ratzinger / Benedict XVI, who made a very important contribution regarding the aim of this work. In this way, the basic results of the research come to light: the sacred texts have to be interpreted in the light of the unity and harmony of Scripture and proceeding from its center - Jesus Christ. The most appropriate methodological procedure for such an interpretation is the so-called canonical exegesis, which reads an individual Biblical text in the light of the whole of the Old and New Testaments. Sacred tradition, the analogy of faith and typological interpretations play an important role. This also opens the perspective for understanding the concordance of Marian dogmas with God's revelation. Therefore, the Scriptures reveal the layers of biblical tradition that are the stronghold of Mariology and Marian dogmas, namely the Old Testament theology of the woman and the theology of the people of God. All the essential elements of these realities are embodied in Mary. That is why in Mary Israel, but also the Church exist as a person, which is the fundamental biblical-Mariological thesis of J. Ratzinger.

Keywords: Scripture, Sacred Tradition, Exegesis, Marian dogmas, Joseph Ratzinger / Benedict XVI.

\footnotetext{
* Asst. Prof. Boris Vulić, Ph. D., Catholic Faculty of Theology in Đakovo, J. J. Strossmayer University of Osijek, P. Preradovića St 17, P. O. box 54, 31400 Đakovo, Croatia, vulic@me.com
} 